\title{
Окремі аспекти проблемних питань в управлінні оборонними ресурсами
}

\author{
Олексій Постніков ${ }^{1}$ А; Сергій Ясенко ${ }^{2}$ А; Дмитро Дриньов 3 А \\ А Національний університет оборони України імені Івана Черняховського, пр-кт Повітрофлотський 28, м. Київ, 03049, Україна
}

Received: January 30, 2020 | Revised: February 26, 2021 | Accepted: February 28, 2021

DOI: $10.33445 /$ sds.2021.11.1.20

\begin{abstract}
Анотація
3 початку 2000-х людство поступово ввійшло в чергову активну фазу змін на фоні змін соціальної, політичної, технологічної природи. Крім того, посилився розрив між розвинутими та іншими країнами, що супроводжується розривом у понятійному апараті через зміну самої сутності відносин, включно з управлінською діяльністю (менеджментом) у соціальних групах (колективах). 3 метою не відставання від міжнародних практик управлінської діяльності в статті наведено основні принципи стандартів щодо побудови та управління процесами з управління ресурсами в країнах-членах HATO (ISO 9000, PMBOK, PRINCE2 тощо). Проведено частковий аналіз системи управлінні оборонними ресурсами в Україні. Розглянуто процес управління ресурсами в Міністерстві оборони України (МОУ) та Збройних Силах України (ЗСУ), як основних державних органів в сфері управління оборонними ресурсами. Виявлено недоліки в системі управління ресурсами та сформовано певні пропозиції щодо удосконалення процесу управління оборонними ресурсами.
\end{abstract}

Ключові слова: ресурси, оборонні ресурси, процедура, процес, проєкт, управління ресурсами.

\section{Постановка проблеми}

У 2016-му році Кабінетом Міністрів України було розроблено та затверджено “Стратегію реформування державного управління України на період до 2021 року" [1] та план заходів з їі реалізації, що відповідають європейським стандартам належного урядування.

Один із ключових етапів реформи - це підвищення спроможності міністерств, перетворення їх на потужні аналітичні центри, що будуть сфокусовані на формуванні політик, стануть лідерами у впровадженні реформ і підвищать ефективність діяльності.
В рамках реформування та зазначеної стратегії в МОУ та зСУ виконуються окремі заходи оборонної реформу на середньострокову перспективу. Здійснюється робота щодо реалізації серії проєктів з удосконалення системи управління ресурсами.

3 огляду на зазначене виникає гостра необхідність в аналізі міжнародних практик управління ресурсами з метою впровадження найкращих здобутків в слабких місцях управління ресурсами та прискорення інтеграції України з країнами-членами НАТО.

\section{Аналіз останніх досліджень та публікацій}

На даний час в Україні надзвичайно мало вітчизняних вчених приділяє увагу проблемам управління оборонним ресурсами, хоча останнім часом цей напрямок все більше починає обговорюватися в наукових колах. Зважаючи на такий стан речей можна 3 впевненістю говорити, що цей напрямок $€$ надзвичайно перспективним для проведення

\footnotetext{
${ }^{1}$ Corresponding author: старший науковий співробітник лабораторії центру, e-mail: nyck1985@ukr.net, ORCID: 0000-0003-0581-2131

2 к.в.н., старший викладач кафедри, e-mail: nyck1985@ukr.net, ORCID: 0000-0003-1918-9459

${ }^{3}$ старший офіцер відділу, е-mail: nyck1985@ukr.net
} 
наукових досліджень.

3 наявних наукових досліджень вітчизняних вчених уваги заслуговує праця Кірпічнікова Ю. А., Андрощука О. В., Петрушенка Н. В. та
Васюхна С. І. щодо питань побудови архітектури інформаційної системи управління оборонними ресурсами [2].

\section{Постановка завдання}

Метою статті $\epsilon$ аналіз стандартів щодо побудови та управління процесами 3 управління ресурсами в країнах-членах НАТО та формування пропозиції щодо удосконалення процесу управління ресурсами в МОУ та ЗСУ.

\section{Виклад основного матеріалу}

Загалом, прийнято вважати, що спосіб опису діяльності (функції) поділяють на процедурний, процесний, та проєктний. Слід зазначити, для повноцінного опису процесу потрібно мати модель процедур, які застосовуються в ході виконання процесу, а проєктна діяльність побудована 3 оптимізованих процесів на основі типових.

Сьогодні відсутні ознаки активної дій в сфері стандартизації процесної діяльності, що може означати певну усталеність підходів. В стандартах серії ISO 9000 [3] доцільно згадати модель досконалості менеджменту EFQM (для органів публічної (державної) влади CAF). На подобу до американського стандарту управління проєктами РМВОК [4], є стандарт з управління процесами ВРМ СВОК [5].

Основою представлення процесів $€$ досить проста модель, яку свого часу було використано у британському стандарті BS 6143:Part 1:1992 "Guide to the economics of quality. Part 1: Process cost model" [6]. Зокрема там зазначено, що загальний (тотальний) менеджмент якості вимагає управління процесами, а не тільки кінцевими результатами. Це визнається основою покращення якості та продуктивності i виробничих, і сервісних організацій. За стандартом BS 6143, кожен співробітник організації обслуговує якийсь процесу i вносить свій внесок у нього, кожен процес повинен мати конкретного власника, який відповідає за ефективність цього процесу.

Концепція управління ВРМ СВOK Version 3.0 (ВРМ) [5] зв'язує стратегію і цілі організації 3 очікуваннями і потребами клієнтів (замовників, споживачів) шляхом відповідної організації наскрізних процесів. ВРМ з'єднує в одно стратегію, цілі, культуру і організаційну структуру, ролі, політики, нормативи, методології та програмні засоби задля наступного:

а) аналізу, проєктування, впровадження, управління та безперервного покращення наскрізних процесів;

б) регулювання відносин в сфері процесного управління.

Для опису управління ресурсами в МОУ та ЗСУ у вигляді процесу необхідно визначити тип організації - функціональна (процедурна), процесна чи проєктна. Далі виконують дві паралельні задачі - опис системи управління ресурсами за принципом “як $\epsilon$ " i “як треба". Це може загалом передбачати етапи виконані у послідовний чи послідовно-паралельний спосіб, а саме:

опис стратегічної рамки (Місія (Призначення) - Візія - Цінності), суб'єктів і об'єктів діяльності;

опис внутрішнього та зовнішнього контексту діяльності з використанням різних технік стратегічного аналізу (SWOT, PESTLE тощо);

опис цілей та показників;

опис діяльності, як послідовність процесів (а іноді окремих заходів та проєктів);

опис необхідних для виконання діяльності ресурсів;

інші елементи системи управління (управління якістю, управління ризиками, управління безпекою, управління людським капіталом, управління спроможностями, управління змінами тощо).

Сьогодні, з врахуванням статусу стандартів ISO 9000, найпоширенішою простою схемою процесу $є$ наведена у зазначених стандартах. 
Крім того, розділ 4 стандарту ISO 9001 встановлює всебічні вимоги до організації щодо визначення та застосування процесів, необхідних для її системи менеджменту якості з врахуванням циклу PDCA (Плануй Роби - Перевіряй - Дій) для постійного покращення у поєднанні з мисленням, на основі оцінювання ризиків. Зазначена вище модель представлена у вигляді діаграми SIPOC (постачальник - вхід - процес - вихід - замовник). Типова послідовність дій 3 управління процесом представлена наступною діаграмою (мал. 1).

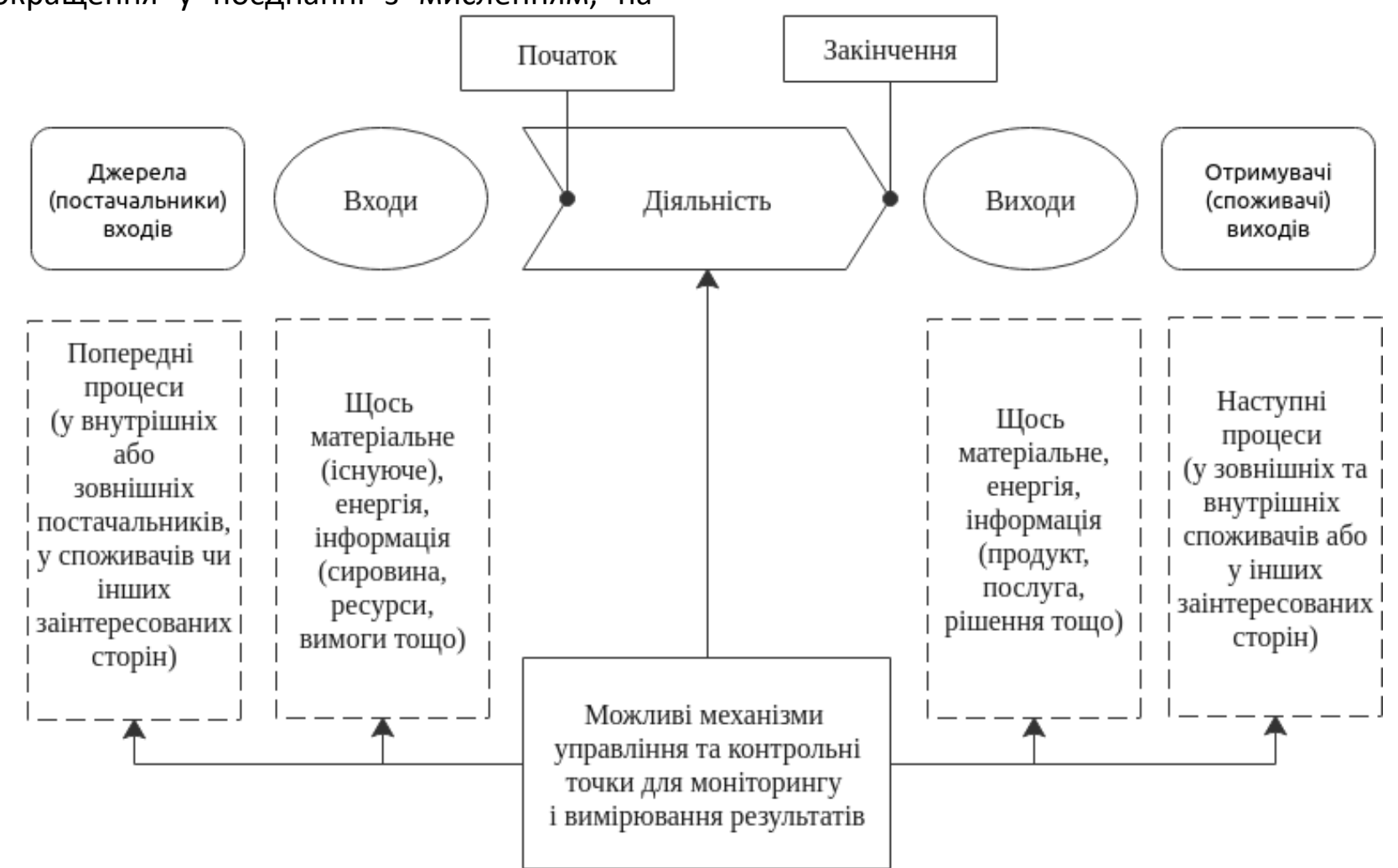

Малюнок 1. Діаграма SIPOC (supplier, input, process, output, customer - постачальник, вхід, процес, вихід, замовник) [7]

Розглядаючи проблеми які назріли під час управління ресурсами в МОУ та ЗСУ необхідно відштовхуватись від завдань які повинні бути досягнуті при управлінні ресурсами. Тобто, якщо діюча система управління ресурсами виконує поставлені перед нею завдання то продуктом $\epsilon$ результати діяльності, які можна покращувати.

Існуюча система управління ресурсами була протестована та пройшла випробування під час ведення бойових дій на сході України. Отримані оцінки та висновки щодо ефективності діючої системи управління ресурсами говорять проте, що вона не достатньо ефективно забезпечує існуючі потреби. Таким чином, реформування існуючої системи управління ресурсами, 3 врахуванням інтеграції України в
Євроатлантичний простір, залишається актуальною задачею.

Активні заходи з реформування системи управління ресурсами в МОУ та ЗСУ розпочато ще в 2014 році. Одним з перших документів планування реформ $€$ введене в дію Указом Президента України від 20 травня 2016 року рішення Ради національної безпеки і оборони України "Про Стратегічний оборонний бюлетень України" (СОБ) в якому зазначено першочергові цілі яких необхідно досягнути в реформі управління ресурсами [8].

За результатами аналізу виконання заходів визначених у СОБ 2016 року щодо управління оборонними ресурсами виявлено, що багато важливих питань (ризиків) не увійшли до даної редакції та потребують додаткового розгляду, а саме: 
1. Існуюча нормативно-правова база, яка врегульовує питання управління ресурсами, знаходиться в процесі оновлення яке відбувається на всіх рівнях управління. Серед іншого відбувається розроблення та уточнення документів в яких визначаються основні концептуальні положення системи управління ресурсами. Одним із таких документів $\in$ "Доктрина Управління оборонними ресурсами" напрямком покращення якої $\epsilon$ доопрацювання визначення об'єктів управління бажано 3 дотриманням положень антологічного підходу, а саме чіткого дотримання моделі (триплету) “суб'єкт - об'єкт - предикат (дія)", опрацювання таксономій (класифікацій) щодо об'єктів суб'єктів та дій, формування єдиного словника управління ресурсами, що має бути під управлінням (постійно актуалізуватись). Разом з цим, потребує розроблення та уточнення набір документів нижчого рівня який забезпечить впровадження положень згаданої Доктрини в діяльність ЗСУ та інших складових сил оборони.

2. Потребує уточнення та розподілу ролей і відповідальності за виконання функцій 3 управління ресурсами між МОУ та органами управління ЗСУ.

3. Станом на сьогодні формування кваліфікаційної рамки щодо персоналу який задіяний у заходах реформування системи управління ресурсами знаходиться на початковому етапі. Підвищення кваліфікації персоналу який задіяний до реформування системи управління ресурсами здійснюється фрагментарно, відсутня системність у підготовці та у використанні отриманих персоналом компетентностей на практиці.

4. Відомим інструментом покращення системи менеджменту $\epsilon$ використання інструменту "бенчмаркінгу" (порівняння). Яскравим прикладом цього $€$ використання кращих логістичних практик системи забезпечення сил НАТО. Разом з тим, в Україні організація взаємодії з логістичними агенціями та асоціаціями знаходиться на низькому рівні. Наприклад фактичне активне залучення логістичних компаній України (таких як “Новая Почта" і “Укрпошта" тощо) в підтримці ЗСу під час збройних агресії Російської Федерації вивчено та враховано недостатньо. Використання цивільних логістичних агенцій не передбачено в доктринальних документах 3 управління ресурсами.

5. Основною частиною особового складу органів управління та підрозділів логістики ЗСУ $є$ фахівці колишніх Тилу та Озброєння ЗСУ, які в умовах впровадження принципів та підходів НАТО до логістичного забезпечення потребують підвищення рівня компетенції та кваліфікації. Також, слід зазначити, що 3 врахуванням вимог до термінів реформування (2024 рік за програмою Президента України) встановлені жорсткі вимоги до потужностей системи підвищення кваліфікації (освіти) та особливі вимоги до координації заходів з підготовки особового складу з подальшим їхнім призначенням на посаду.

6. Однією 3 вимог НАТО щодо забезпечення сумісності $\epsilon$ дотримання принципу модульності, який на практиці означає використання типових сил і засобів 3 внутрішніми процесами визначними на національному рівні в складі міжнаціональних угруповань з уніфікованими “інтерфейсами” (підходи, способи та засоби організації взаємодії), 3 урахуванням зазначеного необхідно продовжувати заходи з розвитку сумісності з НАТО до рівня коли логістична система України у взаємодії 3 аналогічною системою НАТО буде спроможна забезпечувати міжнаціональне угруповання військ (сил) у конфлікті 3 Російською Федерацією.

3 урахуванням наведеного можна сформулювати перелік проблем в сфері системи управління оборонними ресурсами, а саме:

а) невідповідність рівнів задач і загроз у оборонній сфері, відповідних потреб у ресурсах, можливостям економіки України щодо їх задоволення, включно і через недостатньо ефективні та дієві планування та управління ресурсами, що потребують докорінних змін архітектури управління в 
секторі оборони;

b) відсутня єдина модель управління оборонними ресурсами. Наявна модель управління оборонними ресурсами не передбачає узгодженість трьох окремих процесів - 1)управління розвитком спроможностей, 2) 2планування, програмування, бюджетування та виконання, 3) отримання та розподілу ресурсів;

c) недостатність інформації для прийняття рішень (ситуаційна обізнаність в сфері управління оборонними ресурсам), ускладнене використання гнучких підходів до управління розвитком спроможності;

d) застаріле не ефективне нормативне забезпечення організації оборонних програм державного (національного) рівня, а саме:

- державні програми в оборонній сфері не відповідають вже впровадженим в Україні чинним вимогам до таких програм, наприклад через відсутність строків виконання та потреб встановлення відповідної системи моніторингу та оцінювання;

- державні програми не в повній мірі відповідають міжнародним практикам управління проєктною діяльністю, що ускладнює забезпечення цієї діяльності ресурсами;

- низька стійкість та керованість проєктів. Відсутня регламентація та інституціоналізація адаптивних підходів до управління;

е) відсутність системного підходу до використання несистемного ресурсу (інвестицій приватного сектору, ефективних інструментів залучення громадянського суспільства) до вирішення нагальних потреб оборони;

f) спроможності системи мобілізації ресурсів не відповідають вимогам щодо швидкості залучення людських та інтелектуальних ресурсів, мобілізації промислового потенціалу в кризових умовах. Наявна система мобілізації застаріла та недієва;

g) високі корупційні ризики в існуючій системі управління оборонними ресурсами;

h) якість оборонної продукції в багатьох випадках не відповідає вимогам та потребам сил оборони. Відсутність цілісної системи національних та військових стандартів у сфері менеджменту якості оборонної продукції та управління життєвим циклом.

I) не визначено підходи до опису та управління життєвим циклом спроможності та відповідно вартістю спроможності.

Враховуючи наведене вище існує необхідність у проведенні глибокого реформування системи управління ресурсами в МОУ та ЗСУ. Відповідно до реформи центральних органів виконавчої влади (ЦОВВ) виконавчі інститути повинні бути поділені на установи за функціоналом та процесами, які їм будуть відповідати, а саме:

1) Міністерства - формують і управляють політикою;

2) Служби - надають державні послуги громадянам та юридичним особам (ліцензування, перевірки та аудити, довідки, тощо), наприклад Державіаслужба, Держслужба експортного контролю тощо;

3) Агентства - управляють державним майном і надають послуги юридичним особам щодо державної власності, розробляють i реалізують стратегію (наприклад Національне космічне агентство України, Агентство автомобільних доріг України, Державне агентство резерву України).

Вказане реформування відповідає принципам організації роботи органів виконавчої влади Європейського союзу, а отже $\epsilon$ актуальною на даний час.

Слід зазначити, що реформування системи не повинно закінчуватися тільки на створенні структур органів управління оборонними ресурсами та розподілу між ними ролей і відповідальності. Це також і розробка нормативно-правової бази для функціонування цієї сфери.

Для прикладу спрощена схема системи нормативних документів Сполучених Штатів Америки в сфері оборони в основному поділена на три частини: законодавство, політики, нормативи і правила. Законодавчі документи стосуються Конституційного поля, унормування діяльності і унормування управління ресурсами у різних аспектах. До 
політичної частини системи нормативних документів в сфері оборони відносяться:

- політика Президента, що може бути оголошена у вигляді заяви (промови) Президента перед Сенатом;

- стратегії національної та воєнної безпеки;

- директив, інструкцій та посібників (рекомендацій) Міністерства оборони і Генерального штабу;

- Візії розвитку сектору оборони;
- об'єднаної оперативної концепції; Білої книги Міністерства оборони тощо.

До нормативів і правил (доктринальна частина) відносять дві групи:

доктрин (Capstones i Keystones) польові рекомендації (аналог бойових статутів в Україні, але з іншим статусом) та документи нижчих рівнів;

нормативи видані командувачами на театрах воєнних дій та командувачами операцій.

\section{Висновки}

Система управління оборонним ресурсами в України на даний момент перебуває в фазі докорінного реформування, що повинно забезпечити ії ефективність та сумісність 3 партнерами - країнами-членами НАТО. В той же час вона $\epsilon$ глибоко архаїчною за рахунок залишків старої радянської системи. В зв'язку з цим перед безпосередніми учасниками цих змін, а особливо МОУ та ЗСУ, постають серйозні проблеми щодо створення нової системи управління ресурсами з урахуванням вимог та стандартів розвинутих країн (кранчленів НАТО) в умовах обмеженого ресурсного забезпечення (людського, фінансового тощо). В той же час існує досвід країн-партнерів, які проходили аналогічний шлях для отримання членства в НАТО, який необхідно використовувати.

\section{Список використаних джерел}

1. Деякі питання реформування державного управління України: Постанова Кабінету Міністрів України від 24.06.2016 р. № 474p. URL: https://zakon.rada.gov.ua/laws/ show/474-2016-\%D1\%80\#Text (дата звернення: 15.02.2021).

2. Кірпічніков Ю. А., Андрощук О. В., Петрушенко Н. В. та Васюхно С. І. Теоретичні підходи до побудови архітектури інформаційної ситеми управління оборонними ресурсами на основі сервісно-орієнтованої моделі. Збірник видань ЦВСД НУОУ. 2019. № 2. С. 80-85.

3. ДСТУ ISO 9000:2007. Системи управління якістю. Основні положення та словник термінів (ISO 9000:2005, IDT) [Текст]. Київ : ДП “УкрНДНЦ”, 2008. 35 с.

4. A Guide to the Project Management Body of Knowledge (PMBOK ${ }^{\circledR}$ Guide).

5. BPM CBOK (Business Process Management
Common Body of Knowledge). URL: https://hsbi.hse.ru/articles/bpm-cbokbusiness-process-management-commonbody-of-knowledge/. (дата звернення: 15.02.2021).

6. BS. URL: https://qualitasbiblo.files. wordpress.com/2013/01/bs-6143-1-guideto-the-economics-of-quality-part-1-processcost-model.pdf. (дата звернення: 15.02.2021).

7. Eckes, George. Six Sigma Team Dynamics: The Elusive Key to Project Success. - John Wiley \& Sons, 2003. 262 p.

8. Про рішення Ради національної безпеки i оборони України від 20 травня 2016 року “Про Стратегічний оборонний бюлетень України": Указ Президента України від 06.06.2016 року № 240/2016. URL: https://zakon.rada.gov.ua/laws/show/240/2 016\#n10 (дата звернення: 15.02.2021). 


\title{
Отдельные аспекты проблемных вопросов в управлении оборонными ресурсами
}

\author{
Алексей Постников ${ }^{1 \text { A; }}$ Сергей Ясенко ${ }^{2}$ А; Дмитрий Дринев ${ }^{3 \text { A }}$ \\ ${ }^{1}$ Corresponding author: старший научный сотрудник лаборатории центра, e-mail: nyck1985@ukr.net, ORCID: 0000-0003-0581-2131 \\ ${ }^{2}$ к.в.н., старший преподаватель кафедры, e-mail: nyck1985@ukr.net, ORCID: 0000-0003-0581-2131 \\ ${ }^{3}$ старший офицер отдела, e-mail: nyck1985@ukr.net
}

А Национальный университет обороны Украины имени Ивана Черняховского, пр-кт Воздухофлотский, 28, г. Киев, 03049, Украина

\begin{abstract}
Аннотация
С начала 2000-х человечество постепенно вошло в очередную активную фазу изменений на фоне изменений социальной, политической, технологической природы. Кроме того, усилился разрыв между развитыми и другими странами, сопровождается разрывом в понятийном аппарате через изменение самой сущности отношений, включая управленческой деятельностью (менеджментом) в социальных группах (коллективах). С целью уменшить отставание от международных практик управленческой деятельности, в статье приведены основные принципы стандартов построения и управления процессами по управлению ресурсами в странах-членах HATO (ISO 9000, PMBOK, PRINCE2 и т.д.). Проведен частичный анализ системы управления оборонными ресурсами в Украине. Рассмотрен процесс управления ресурсами в Министерстве обороны Украины (МОУ) и Вооруженных Силах Украины (ВСУ), как основных государственных органов в сфере управления оборонными ресурсами. Выявлены недостатки в системе управления ресурсами и сформированы определенные предложения по совершенствованию процесса управления оборонными ресурсами.
\end{abstract}

Ключевые слова: ресурсы, оборонные ресурсы, процедура, процесс, проект, управление ресурсами.

\section{Some aspects of problematic issues in the management of defense resources}

\author{
Alexey Postnikov ${ }^{1}$ A; Sergey Yasenko ${ }^{2}$ A; Dmytro Drynov 3 A \\ ${ }^{1}$ Corresponding author: senior researcher of the center's laboratory, e-mail: nyck1985@ukr.net, ORCID: 0000-0003-0581-2131 \\ ${ }^{2}$ senior lecturer of the department, e-mail: nyck1985@ukr.net, ORCID: 0000-0003-1918-9459 \\ ${ }^{3}$ senior officer of the department, e-mail:nyck1985@ukr.net
}

A National Defence University of Ukraine named after Ivan Cherniachovskyi, 28, Povitroflotsky, ave, Kyiv, 03049, Ukraine

\begin{abstract}
Since the early 2000s, humanity has gradually entered another active phase of change against the background of changes in social, political, technological nature. In addition, the gap between developed and other countries has widened, accompanied by a gap in the conceptual apparatus due to changes in the very essence of relations, including management (management) in social groups (teams). In order to keep up with international management practices, the article presents the basic principles of standards for the construction and management of resource management processes in NATO member countries (ISO 9000, PMBOK, PRINCE2, etc.). A partial analysis of the defense resources management system in Ukraine was conducted. The process of resource management in the Ministry of Defense of Ukraine (MOU) and the Armed Forces of Ukraine (AFU) as the main state bodies in the field of defense and resource management is considered. Deficiencies in the resource management system have been identified and certain proposals have been made to improve the defense resources management process.
\end{abstract}

Keywords: resources, defense resources, procedure, process, project, resource management. 


\section{References}

1. Deyaki pytannya reformuvannya derzhavnoho upravlinnya Ukrayiny: Postanova Kabinetu Ministriv Ukrayiny vid 24.06.2016 r. № 474-r. Available from: https://zakon.rada.gov.ua/laws/show/4742016-\%D1\%80\#Text (data zvernennya: 15.02.2021).

2. Kirpichnikov YU. A., Androshchuk O. V., Petrushenko N. V. ta Vasyukhno S. I. Teoretychni pidkhody do pobudovy arkhitektury informatsiynoyi sytemy upravlinnya oboronnymy resursamy na osnovi servisno-oriyentovanoyi modeli. Zbirnyk vydan' TSVSD NUOU. 2019. № 2. S. 80-85.

3. DSTU ISO 9000:2007. Systemy upravlinnya yakistyu. Osnovni polozhennya ta slovnyk terminiv (ISO 9000:2005, IDT). Kyiv : DP "UkrNDNTS", 2008. $35 \mathrm{~s}$.

4. A Guide to the Project Management Body of Knowledge (PMBOK ${ }^{\circledR}$ Guide).
5. BPM CBOK (Business Process Management Common Body of Knowledge). Available from: https://hsbi.hse.ru/articles/bpm-cbokbusiness-process-management-commonbody-of-knowledge/. (дата звернення: 15.02.2021).

6. BS. Available from: https://qualitasbiblo.files. wordpress.com/2013/01/bs-6143-1-guideto-the-economics-of-quality-part-1-processcost-model.pdf. (дата звернення: 15.02.2021).

7. Eckes, George. Six Sigma Team Dynamics: The Elusive Key to Project Success. - John Wiley \& Sons, 2003. $-262 \mathrm{p}$.

8. Pro rishennya Rady natsional'noyi bezpeky i oborony Ukrayiny vid 20 travnya 2016 roku "Pro Stratehichnyy oboronnyy byuleten' Ukrayiny": Ukaz Prezydenta Ukrayiny vid 06.06.2016 roku № 240/2016. Available from: https://zakon.rada.gov.ua/laws/show/240/2 016\#n10 (data zvernennya: 15.02.2021). 